\title{
Extratemporal abnormalities in phosphorus magnetic resonance spectroscopy of patients with mesial temporal sclerosis
}

\author{
Anormalidades extratemporais na espectroscopia de fósforo por ressonância magnética \\ em pacientes com esclerose mesial temporal \\ Eun Joo Park', Maria Concepción Garcia Otaduy', Katarina Paz de Lyra', Celi Santos Andrade 1 , Luiz Henrique \\ Martins Castro², Valmir Passarelli², Rosa Maria Figueiredo Valerio², Carmen Lisa Jorge ${ }^{2}$, Miriam Harumi Tsunemi, \\ Claudia da Costa Leite
}

\begin{abstract}
Objective: We evaluated extratemporal metabolic changes with phosphorus magnetic resonance spectroscopy $\left({ }^{31} \mathrm{P}-\mathrm{MRS}\right)$ in patients with unilateral mesial temporal sclerosis (MTS). Method: ${ }^{31} \mathrm{P}-\mathrm{MRS}$ of 33 patients with unilateral MTS was compared with $31 \mathrm{controls}$. The voxels were selected in the anterior, posterior insula-basal ganglia (AIBG, PIBG) and frontal lobes (FL). Relative values of phosphodiesters- PDE, phosphomonoesters-PME, inorganic phosphate - Pi, phosphocreatine- PCr, total adenosine triphosphate $\left[\right.$ ATP $\left._{t=} \gamma^{-}+a-+b-A T P\right]$ and the ratios PCr/ATP ${ }_{t,}$ PCr/ $\gamma$-ATP, PCr/Pi and PME/PDE were obtained. Results: We found energetic abnormalities in the MTS patients compared to the controls with Pi reduction bilaterally in the AIBG and ipsilaterally in the PIBG and the contralateral FL; there was also decreased PCr/ $\gamma$-ATP in the ipsilateral AIBG and PIBG. Increased ATP in the contralateral AIBG and increased $\gamma$-ATP in the ipsilateral PIBG were detected. Conclusion: Widespread energy dysfunction was detected in patients with unilateral MTS.
\end{abstract}

Keywords: phosphorus spectroscopy, magnetic resonance imaging, neurometabolism, mesial temporal sclerosis, epilepsy.

\section{RESUMO}

Objetivo: Nós avaliamos as alterações metabóblicas através da espectroscopia de fósforo por ressonância magnética (31P-MRS) em pacientes com esclerose mesial temporal (EMT) unilateral. Método: ${ }^{31} \mathrm{P}-\mathrm{MRS}$ de 33 pacientes com EMT unilateral foram comparadas aos de 31 controles. Foram selecionados os voxels nas regiões insulonuclear anterior e posterior (RINA e RINP) e frontal (RF). Os valores relativos de fosfodiésteres - PDE, fosfomonoésteres- PME, fosfato inorgânico- Pi, fosfocreatina -PCr, adenosina trifosfato total [ATP $\left.\gamma_{t} \gamma-+a-+b-A T P\right]$ e as razões PCr/ATP ${ }_{t}$ PCr/ $\gamma$-ATP, PCr/Pi e PME/PDE foram obtidas. Resultados: Nós encontramos anormalidades em pacientes com EMT em comparação aos controles. Redução de Pi nas RINA bilateralmente, RINP ipsilateral e RF contralateral, redução de PCr/ $\gamma$-ATP nas RINA e RINP ipsilaterais foram detectadas. Aumentos de ATP , na RINA contralateral e aumento de $\gamma$-ATP na RINP ipsilateral também foram encontradas. Conclusão: Disfunção energética difusa foi encontrada em pacientes com EMT unilateral.

Palavras-chave: espectroscopia de fósforo, ressonância magnética, neurometabolismo, esclerose mesial temporal, epilepsia.

Temporal lobe epilepsy (TLE) is the most common form of epilepsy in adult patients and the mesial temporal sclerosis (MTS) is the most frequent entity associated with medically refractory TLE. MTS is characterized by selective neuronal loss in CA1, CA3 and the dentate gyrus of the hippocampus. MTS may also involve the amygdala, parahippocampal gyrus, and entorhinal cortex. More widespread temporal lobe involvement may also occur ${ }^{1}$.

Previous studies have discovered metabolic dysfunction in the temporal and extratemporal regions in mesial temporal sclerosis. Interictal ${ }^{18}$-FDG-PET studies in $\mathrm{MTS}^{2}$ have shown ipsiand contralateral decreased glucose metabolism not only in the temporal lobe but also in the basal ganglia ${ }^{3}$ and frontal lobes ${ }^{4}$. These findings are in agreement with proton magnetic resonance spectroscopy ( $\left.{ }^{1} \mathrm{H}-\mathrm{MRS}\right)$, phosphorous magnetic resonance spectroscopic imaging $\left({ }^{31} \mathrm{P}-\mathrm{MRS}\right)^{5}$ and single-photon emission computed tomography (SPECT) $)^{6}$ studies in which extensive temporal and extratemporal structural and metabolic involvement in epilepsy has been associated with MTS.

\footnotetext{
${ }^{1}$ Universidade de São Paulo, Faculdade de Medicina, Departamento de Radiologia, Sao Paulo SP, Brazil;

${ }^{2}$ Universidade de São Paulo, Faculdade de Medicina, Departamento de Neurologia, Sao Paulo SP, Brazil;

${ }^{3}$ Universidade Estadual Paulista Júlio de Mesquita Filho, Instituto de Biociências, Botucatu SP, Brazil.

Correspondence: Eun Joo Park; Rua Aimbere, 909 / apt.24; 05018-011 Sao Paulo SP, Brasil; E-mail: ejpark_br@hotmail.com

Conflict of interest: There is no conflict of interest to declare.

Received 19 June 2015; Received in final form 04 October 2015; Accepted 26 October 2015.
} 
${ }^{1} \mathrm{H}-\mathrm{MRS}$ studies have reported decreased $N$-acetylaspartate/creatine (NAA/Cr) in ipsilateral mesial temporal structures compared to the contralateral side and to controls ${ }^{7,8}$ with $87 \%$ sensitivity, $92 \%$ specificity and lateralization in $86 \%$ of patients ${ }^{9,10}$. Significant decreases in the NAA/Cr ratio were also found in the contralateral hippocampus and thalami ${ }^{11}$, as well as in the frontal, parietal and occipital lobes bilaterally compared to control group ${ }^{7}$. These findings were more pronounced in the ipsilateral hemispheres of MTS patients compared to controls ${ }^{7}$. Patients who presented with bitemporal or extratemporal abnormalities on ${ }^{18}$-FDG-PET and ${ }^{1} \mathrm{H}$-MRS have poorer surgical outcomes ${ }^{12}$ and more severe cognitive impairment ${ }^{4}$ than patients who presented with unilateral temporal changes.

Phosphorous magnetic resonance spectroscopic imaging ( ${ }^{31} \mathrm{P}$ - MRS) allows a non-invasive measurement of the phosphorus metabolites related to the energy state and membrane composition as well as an evaluation of mitochondrial function, considering that ATP is mainly generated by mitochondria ${ }^{13}$.

Previous studies have investigated the lateralizing ability of ${ }^{31} \mathrm{P}-\mathrm{MRS}$ in patients with TLE. These studies found reduced PCr/Pi and PCr/ATP ratios in the temporal lobes, which was more pronounced ipsilaterally, allowing for correct seizure focus lateralization in 70 to $73 \%$ of $\operatorname{cases}^{14}$. In extratemporal locations, decrease of $\mathrm{PCr} / \gamma$-ATP ratio in the patient's ipsilateral parietal gray matter compared to the same region in controls ${ }^{14}$ and reduced $\mathrm{PCr} / \mathrm{ATP}$ ratios were found bilaterally in the hippocampi and ipsilaterally in the thalamus and striatum ${ }^{15}$.

The temporal lobe metabolic abnormalities were well characterized by the methods mentioned above however, further characterization of the extratemporal abnormalities in MTS, specially considering the information that ${ }^{31} \mathrm{P}$ - MRS can provide, can facilitate our understanding of the extent of metabolic dysfunction and their role in refractoriness to clinical treatment, as well as of the cognitive and psychiatric impairment associated with refractory epilepsy. This characterization may also contribute for predicting the postoperative outcome.

There are few reports in the literature regarding ${ }^{31} \mathrm{P}-\mathrm{MRS}$ in patients with MTS, most of which with small sample sizes, some performed in low magnetic field. The aim of this study was to use ${ }^{31} \mathrm{P}$ - MRS to evaluate extratemporal metabolic changes in a strict, large selection of patients with refractory epilepsy related to unilateral MTS.

\section{METHOD}

\section{Subjects}

We analyzed a consecutive series of patients with TLE secondary to unilateral MTS. Diagnosis of TLE was established by MRI and EEG findings. Brain MRI findings of unilateral hippocampal volume loss on T1-weighted images and increased signal intensity on T2-weighted and/or FLAIR images, without other MRI lesions except minor white matter changes on T2 or FLAIR sequences, also supported the diagnosis of MTS. All patients presented with medically refractory epilepsy and were in the process of surgical evaluation. All patients underwent prolonged video-EEG monitoring with recording of at least one epileptic seizure and had electrographic onset in the temporal lobe. Patients with other neurological or active psychiatric disease, previous or current ethanol abuse and comorbidity with nonepileptic psychogenic seizures were excluded. Healthy controls, fulfilling the other inclusion and exclusion criteria served as a control group.

We studied 33 patients (20 women, age range 23 to 55 years, mean age $35.9 \pm 9.7$ years) and 31 controls ( 19 women, age range 18 to 53 years, mean age $32.5 \pm 9.9$ years). All patients reported being seizure-free for at least 48 hours prior to MRS examination.

The institution ethics committee approved this study. All patients and controls signed the approved informed consent form prior to study enrollment.

\section{${ }^{31} \mathrm{P}-\mathrm{MRS}$}

Three-dimensional (3D) ${ }^{31} \mathrm{P}-\mathrm{MRS}$ was performed on an Intera Achieva 3.0 T system (Philips, Best, The Netherlands) using a double-tuned ${ }^{31} \mathrm{P} /{ }^{1} \mathrm{H}$ head coil (AIRI, Cleveland, USA). A T1-fast field echo axial sequence was acquired (TR $=7.6 \mathrm{~ms}$; $\mathrm{TE}=3.7 \mathrm{~ms}$; flip angle $=8^{\circ}$; isotropic $1-\mathrm{mm}^{3}$ resolution) with sagittal and coronal plane reconstructions.

${ }^{31} \mathrm{P}-\mathrm{MRS}$ acquisition was based on a pulse-acquire type sequence $(\mathrm{TE} / \mathrm{TR}=0.31 \mathrm{~ms} / 5093 \mathrm{~ms})$, using an adiabatic pulse, broadband decoupling (power factor $=0.4$; offset $=100 \mathrm{~Hz}$ ) and an automatic shimming procedure. Saturation bands were placed around the grid to avoid muscle contamination. The total field of view was 180 x 210 x $120 \mathrm{~mm}$ (right to left $\mathrm{x}$ anterior to posterior $\mathrm{x}$ superior to inferior), divided into six slices with six columns and seven lines each, resulting in 30 x 30 x 20 mm individual voxels. Following ${ }^{31}$ P-MRS acquisition, low resolution $\mathrm{T} 1$ images $(\mathrm{TR}=9.4 \mathrm{~ms}$; $\mathrm{TE}=4.6 \mathrm{~ms}$; flip angle $=8^{\circ}$; section thickness $=3 \mathrm{~mm}$ ) were obtained to ensure the same head location throughout the examination. The total exam time was 43 minutes.

Spectral processing and quantification were performed with jMRUI software using the AMARES algorithm ${ }^{16}$. The postprocessing included truncation of the first two data points to reduce the baseline broadline component distortion effects. Starting values for line-width constraints, chemical shifts and J coupling were used as prior knowledge in the fitting algorithm. Zero- and first-order phase corrections were applied for convergence during spectral fitting.

These steps were repeated for all analyzed voxels and were always performed by the same investigator.

The relative values of each metabolite divided by the sum of all metabolites (phosphodiesters- PDE, phosphomonoesters-PME, 
Table 1. Comparison of the metabolite profile in the ipsilateral regions.

\begin{tabular}{|c|c|c|c|c|c|c|}
\hline \multirow{2}{*}{ Location } & \multirow{2}{*}{$\begin{array}{l}\text { Metabolites } \\
\text { and ratios }\end{array}$} & \multicolumn{2}{|c|}{ Patients } & \multicolumn{2}{|c|}{ Controls } & \multirow{2}{*}{$p$-value } \\
\hline & & mean & SD & mean & SD & \\
\hline \multirow[t]{10}{*}{ AlBG } & $\mathrm{Pi}$ & 0.081 & 0.013 & 0.089 & 0.007 & 0.009 \\
\hline & $\mathrm{PCr}$ & 0.194 & 0.017 & 0.198 & 0.014 & 0.289 \\
\hline & $\gamma$-ATP & 0.100 & 0.014 & 0.094 & 0.011 & 0.071 \\
\hline & $\mathrm{ATP}_{\mathrm{T}}$ & 0.293 & 0.022 & 0.286 & 0.018 & 0.165 \\
\hline & $\mathrm{PCr} / \mathrm{ATP}_{\mathrm{T}}$ & 0.668 & 0.100 & 0.699 & 0.081 & 0.183 \\
\hline & $\mathrm{PCr} / \gamma$-ATP & 1.966 & 0.310 & 2.146 & 0.327 & 0.027 \\
\hline & $\mathrm{PCr} / \mathrm{Pi}$ & 2.465 & 0.599 & 2.264 & 0.235 & 0.081 \\
\hline & PME & 0.173 & 0.017 & 0.174 & 0.014 & 0.706 \\
\hline & PDE & 0.196 & 0.018 & 0.194 & 0.015 & 0.616 \\
\hline & PME/PDE & 0.889 & 0.133 & 0.903 & 0.086 & 0.604 \\
\hline \multirow[t]{10}{*}{ PIBG } & $\mathrm{Pi}$ & 0.077 & 0.011 & 0.083 & 0.008 & 0.009 \\
\hline & $\mathrm{PCr}$ & 0.197 & 0.017 & 0.200 & 0.012 & 0.520 \\
\hline & $\gamma$-ATP & 0.098 & 0.009 & 0.093 & 0.009 & 0.024 \\
\hline & $\mathrm{ATP}_{\mathrm{T}}$ & 0.294 & 0.019 & 0.286 & 0.019 & 0.080 \\
\hline & $\mathrm{PCr} / \mathrm{ATP}_{\mathrm{T}}$ & 0.674 & 0.085 & 0.704 & 0.075 & 0.132 \\
\hline & $\mathrm{PCr} / \gamma$-ATP & 2.023 & 0.249 & 2.194 & 0.306 & 0.017 \\
\hline & $\mathrm{PCr} / \mathrm{Pi}$ & 2.629 & 0.533 & 2.437 & 0.303 & 0.081 \\
\hline & PME & 0.167 & 0.013 & 0.168 & 0.011 & 0.739 \\
\hline & PDE & 0.206 & 0.015 & 0.207 & 0.016 & 0.736 \\
\hline & PME/PDE & 0.817 & 0.088 & 0.819 & 0.082 & 0.929 \\
\hline \multirow[t]{10}{*}{$\mathrm{FL}$} & $\mathrm{Pi}$ & 0.088 & 0.012 & 0.093 & 0.010 & 0.106 \\
\hline & $\mathrm{PCr}$ & 0.195 & 0.021 & 0.195 & 0.015 & 0.941 \\
\hline & $\gamma$-ATP & 0.102 & 0.014 & 0.101 & 0.011 & 0.977 \\
\hline & $\mathrm{ATP}_{\mathrm{T}}$ & 0.296 & 0.019 & 0.303 & 0.016 & 0.121 \\
\hline & $\mathrm{PCr} \mathrm{ATP}_{\mathrm{T}}$ & 0.663 & 0.107 & 0.645 & 0.069 & 0.420 \\
\hline & $\mathrm{PCr} / \gamma$-ATP & 1.969 & 0.418 & 1.957 & 0.303 & 0.892 \\
\hline & $\mathrm{PCr} / \mathrm{Pi}$ & 2.252 & 0.443 & 2.139 & 0.279 & 0.233 \\
\hline & PME & 0.175 & 0.017 & 0.173 & 0.012 & 0.689 \\
\hline & PDE & 0.185 & 0.018 & 0.180 & 0.016 & 0.261 \\
\hline & PME/PDE & 0.954 & 0.131 & 0.971 & 0.099 & 0.560 \\
\hline
\end{tabular}

AIBG: anterior insula-basal ganglia regions; PIBG: posterior insula-basal ganglia regions; FL: frontal lobes. $\gamma$-ATP: gamma adenosine triphosphate; Pi: inorganic phosphate; PCr: phosphocreatine; PDE: phosphodiesthers-; PME: phosphomonoesthers-; ATP: total adenosine triphosphate; SD: standard deviation; $p$-value obtained with student's t-test. inorganic phosphate - $\mathrm{Pi}$, phosphocreatine- $\mathrm{PCr}$, total adenosine triphosphate ATP $\left.\left._{t=} \gamma-+a-+b-A T P\right]\right)$, as well as the metabolite ratios $\mathrm{PCr} / \mathrm{ATP}_{\mathrm{t}}, \mathrm{PCr} / \gamma$-ATP, PCr/ $\gamma$-ATP, PCr/Pi and PME/PDE, were obtained for patients and controls. A typical ${ }^{31} \mathrm{P}-\mathrm{MRS}$ is presented in Figure 1.

Although a large number of voxels was obtained, to avoid multiple comparisons errors, muscle contamination and to provide reproducibility, the most homologous voxels in the basal ganglia and frontal lobes were analyzed. Therefore, we selected the anterior insula-basal ganglia (AIBG) regions, posterior insula-basal ganglia (PIBG) regions and frontal lobes (FL) voxels (Figure 2), located ipsi- or contralaterally to the MTS.

\section{Statistical analysis}

All metabolite measurements and studied ratios of each selected voxel for the patients were compared to the average values of controls.

The $t$ test was used to compare groups; $\mathrm{p}<0.05$ was considered statistically significant. Statistical analyses were performed with the SPSS version 17.0.1 software package (SPSS Inc., Chicago, IL, U.S.A.).

\section{RESULTS}

Twenty patients with left MTS and 13 patients with right MTS were studied.

In the ipsilateral AIBG, we found reduced $\mathrm{Pi}$ ( patients $=0.081$ vs. controls $=0.089, p=0.009)$ and $\mathrm{PCr} / \gamma$-ATP (patients $=1.966$ vs. controls $=2.146, p=0.027)$ in the patients compared to controls (Table 1 ).

In the contralateral AIBG, we detected reduced Pi (patients $=0.082$ in patients vs. controls $=0.089, \mathrm{p}=0.013)$ and increased total ATP (patients $=0.298$ vs. controls $=0.286$, $\mathrm{p}=0.026$ ) in the patients compared to controls (Table 2).

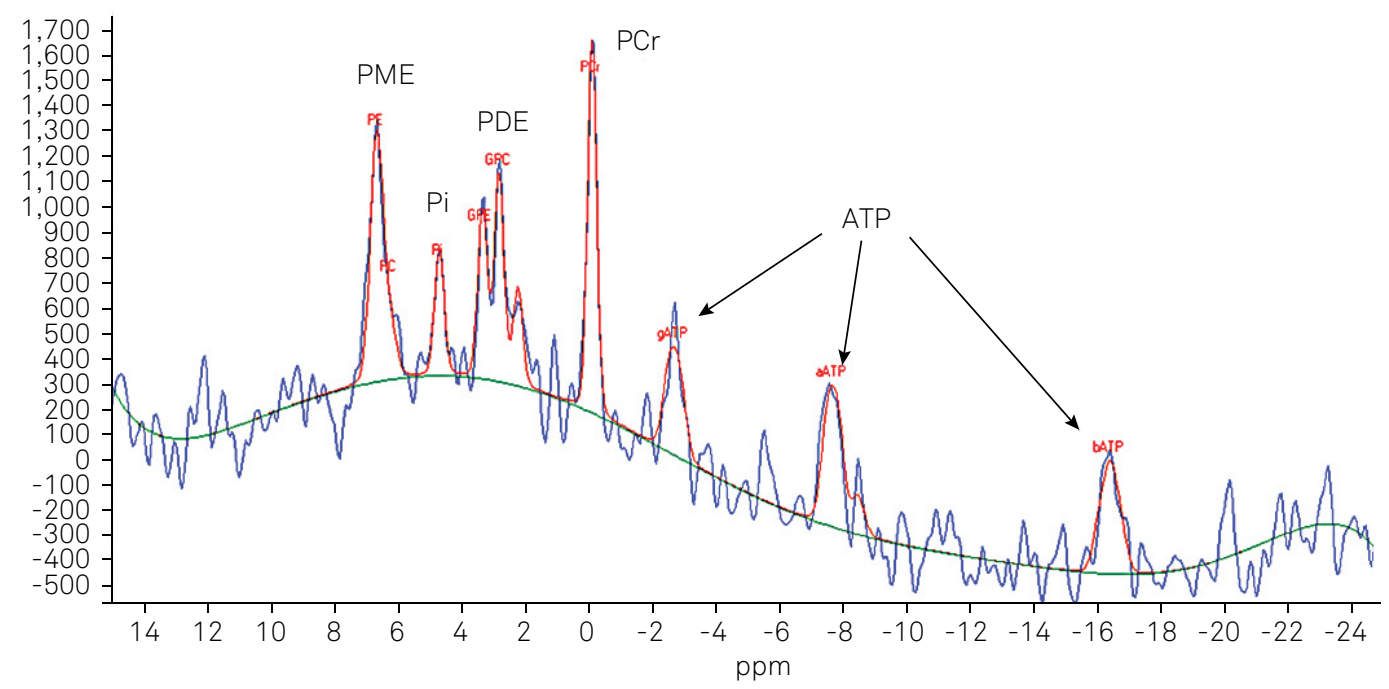

Figure 1. Normal ${ }^{31}$ P- MRS: PCr (phosphocreatine), Pi (inorganic phosphate), $\gamma^{-}, \alpha^{-}, \beta$-ATP (adenosine triphosphate) representing energetic pool. PME (phosphomonoesters), PDE (phosphodiesters) representing membrane turnover. 

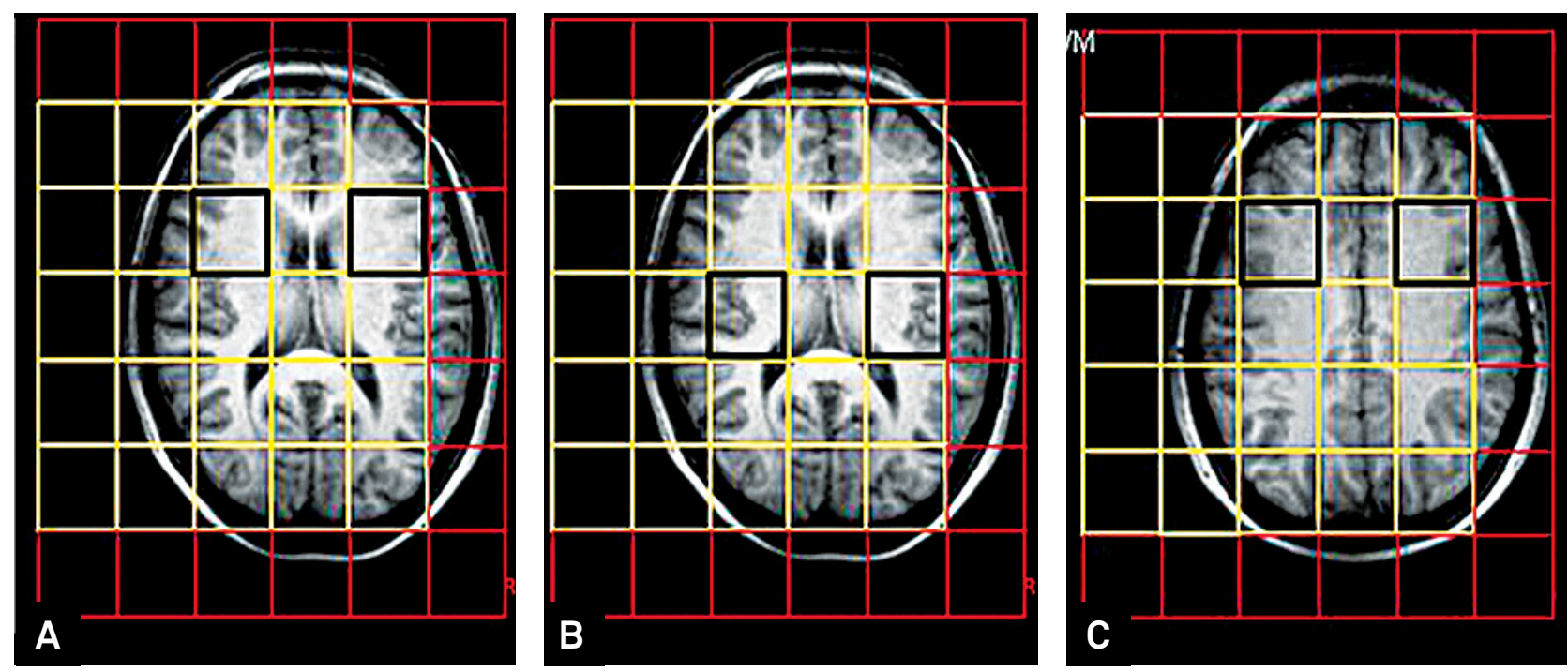

Figure 2. Location of the selected voxels. (A) Anterior insula-basal ganglia (AIBG) regions. (B) Posterior insula-basal ganglia (PIBG) regions (C). Frontal lobes (FL).

Table 2. Comparison of the metabolite profile in the contralateral regions.

\begin{tabular}{|c|c|c|c|c|c|c|}
\hline \multirow{2}{*}{ Location } & \multirow{2}{*}{$\begin{array}{l}\text { Metabolites } \\
\text { and ratios }\end{array}$} & \multicolumn{2}{|c|}{ Patients } & \multicolumn{2}{|c|}{ Controls } & \multirow{2}{*}{$p$-value } \\
\hline & & mean & SD & mean & SD & \\
\hline \multirow[t]{10}{*}{ AlBG } & $\mathrm{Pi}$ & 0.082 & 0.011 & 0.089 & 0.007 & 0.013 \\
\hline & $\mathrm{PCr}$ & 0.194 & 0.017 & 0.198 & 0.014 & 0.369 \\
\hline & $\gamma$-ATP & 0.099 & 0.013 & 0.094 & 0.011 & 0.101 \\
\hline & $\mathrm{ATP}_{\mathrm{T}}$ & 0.298 & 0.025 & 0.286 & 0.018 & 0.026 \\
\hline & $\mathrm{PCr} / \mathrm{ATP}_{\mathrm{T}}$ & 0.659 & 0.105 & 0.699 & 0.081 & 0.096 \\
\hline & $\mathrm{PCr} / \gamma$-ATP & 1.996 & 0.376 & 2.146 & 0.327 & 0.095 \\
\hline & PCr/Pi & 2.409 & 0.447 & 2.264 & 0.235 & 0.108 \\
\hline & PME & 0.172 & 0.016 & 0.174 & 0.016 & 0.434 \\
\hline & PDE & 0.197 & 0.021 & 0.194 & 0.019 & 0.506 \\
\hline & PME/PDE & 0.886 & 0.163 & 0.903 & 0.104 & 0.184 \\
\hline \multirow[t]{10}{*}{ PIBG } & $\mathrm{Pi}$ & 0.082 & 0.010 & 0.083 & 0.008 & 0.488 \\
\hline & $\mathrm{PCr}$ & 0.195 & 0.015 & 0.200 & 0.012 & 0.219 \\
\hline & $\gamma$-ATP & 0.096 & 0.013 & 0.093 & 0.009 & 0.300 \\
\hline & $\mathrm{ATP}_{\mathrm{T}}$ & 0.296 & 0.024 & 0.286 & 0.019 & 0.074 \\
\hline & $\mathrm{PCr} / \mathrm{ATP}_{\mathrm{T}}$ & 0.668 & 0.100 & 0.704 & 0.075 & 0.103 \\
\hline & $\mathrm{PCr} / \gamma$-ATP & 2.087 & 0.403 & 2.194 & 0.306 & 0.240 \\
\hline & PCr/Pi & 2.424 & 0.372 & 2.437 & 0.303 & 0.879 \\
\hline & PME & 0.167 & 0.014 & 0.168 & 0.011 & 0.601 \\
\hline & PDE & 0.206 & 0.019 & 0.207 & 0.016 & 0.877 \\
\hline & PME/PDE & 0.816 & 0.126 & 0.819 & 0.082 & 0.910 \\
\hline \multirow[t]{10}{*}{$\mathrm{FL}$} & $\mathrm{Pi}$ & 0.087 & 0.010 & 0.093 & 0.01 & 0.014 \\
\hline & $\mathrm{PCr}$ & 0.187 & 0.015 & 0.195 & 0.015 & 0.051 \\
\hline & $\gamma$-ATP & 0.103 & 0.014 & 0.101 & 0.011 & 0.741 \\
\hline & $\mathrm{ATP}_{\mathrm{T}}$ & 0.307 & 0.020 & 0.303 & 0.016 & 0.430 \\
\hline & $\mathrm{PCr} / \mathrm{ATP}_{\mathrm{T}}$ & 0.613 & 0.077 & 0.645 & 0.069 & 0.087 \\
\hline & $\mathrm{PCr} / \gamma$-ATP & 1.869 & 0.354 & 1.957 & 0.303 & 0.291 \\
\hline & PCr/Pi & 2.199 & 0.363 & 2.139 & 0.279 & 0.468 \\
\hline & PME & 0.174 & 0.017 & 0.173 & 0.012 & 0.789 \\
\hline & PDE & 0.185 & 0.019 & 0.180 & 0.016 & 0.294 \\
\hline & PME/PDE & 0.958 & 0.171 & 0.971 & 0.099 & 0.709 \\
\hline
\end{tabular}

AIBG: anterior insula-basal ganglia regions; PIBG: posterior insula-basal ganglia regions; FL: frontal lobes. $\gamma$-ATP: gamma adenosine triphosphate; Pi: inorganic phosphate; PCr: phosphocreatine; PDE: phosphodiesthers-; PME: phosphomonoesthers-; ATP: total adenosine triphosphate; SD: standard deviation; p-value obtained with student's t-test.
In the ipsilateral PIBG, we found reduced Pi (patients $=0.077$ vs. controls $=0.083, p=0.009)$ and $\mathrm{PCr} / \gamma$-ATP (patients $=0.249$ vs. controls $=0.286, p=0.017$ ) as well as increased $\gamma$-ATP (patients $=0.098$ vs. controls $=0.093, \mathrm{p}=0.024)$ in the patients compared to controls (Table 1).

In the contralateral FL, we found reduced Pi in the patients compared to controls (patients $=0.087$ vs. controls $=0.090$, $\mathrm{p}=0.014)$ (Table 2).

The PCr, $\mathrm{PCr} / \mathrm{ATP}_{\mathrm{T}}, \mathrm{PCr} / \mathrm{Pi}, \mathrm{PME}, \mathrm{PDE}$ and PME/PDE values in the patients were not significantly different from controls.

No significant differences were found between the patients and controls in the contralateral PIBG (Table 2) and in the ipsilateral FL (Table 1) for any of the metabolites or ratios.

\section{DISCUSSION}

We found extratemporal energy metabolism abnormality in patients with unilateral MTS.

More extensive metabolic changes involving $\mathrm{Pi}$ and $\mathrm{PCr} / \gamma$-ATP in the AIBG and PIBG were identified. In the FL, the findings were less prominent; the Pi decrease was the only metabolic abnormality noted in the contralateral FL, while none of the metabolites or ratios were abnormal in the ipsilateral FL.

${ }^{31} \mathrm{P}-\mathrm{MRS}$ reflects five primary resonance groups related to the energy metabolism and membrane turnover. $\mathrm{PCr}$, Pi and ATP (encompassing $\gamma$-, a- and b-ATP) are related to the energetic pool. $\mathrm{PCr}$ acts as an energy reservoir. Upon energy demand, $\mathrm{PCr}$ donates a phosphate group to adenoside diphosphate (ADP), which allows for ATP synthesis. Inversely, in resting states and ATP excess, $\mathrm{PCr}$ is produced. ATP is the main energy source for the majority of cellular functions and it is predominately generated by oxidative phosphorylation 
in the mitochondria ${ }^{17}$. The $\mathrm{PCr} / \mathrm{ATP}$ ratio serves as a robust bioenergetics measure, reflecting the cellular energetic demand and production ${ }^{5}$. Pi represents a mixture of the phosphoric acid ions; the concentration of Pi increases upon high energy demand or cellular damage ${ }^{13}$.

While PME represents membrane anabolism, PDE reflects membrane catabolism. Two metabolites from each are detectable in higher resolution spectra: PME is composed of phosphocholine and phosphoethanolamine, while PDE is composed of glycerophosphocholine and glycerophosphoethanolamine. The PME/PDE ratio indicates the membrane turnover ${ }^{13}$.

Previous ${ }^{31} \mathrm{P}-\mathrm{MRS}$ studies discovered energetic changes in the mesial portion of the temporal lobe in MTS patients, with reduced $\mathrm{PCr} / \mathrm{Pi}$, PCr/ATP and $\gamma$-ATP/Pi ratios in the epileptogenic mesial temporal region compared to controls and to the contralateral temporal lobe ${ }^{15}$. Regarding other metabolites, an increased Pi concentration and reduced PME levels were found ipsilateral to the epileptogenic focus ${ }^{18,19}$.

In extratemporal locations, Chu et al. using ${ }^{31} \mathrm{P}-\mathrm{MRS}$ found a decreased $\mathrm{PCr} / \gamma$-ATP ratio in the patient's ipsilateral parietal gray matter compared to the same region in controls ${ }^{14}$. Pan et al found reduced PCr/ATP ratios in the hippocampi bilaterally and in the thalamus and striatum ipsilaterally in patients with unilateral medically refractory mesial $\mathrm{TLE}^{15}$.

The decreased PCr/ATP ratio observed in this study reflects high energy demand, in line with previous ${ }^{31} \mathrm{P}-\mathrm{MRS}$ studies which investigated MTS ${ }^{14,15}$.

Interictal Pi decrease and ATP increase detected in extratemporal sites could be a consequence of frequent seizures and represent a compensatory mechanism to high energetic consumption during the ictal period. The ictal period is characterized by reduced PCr and ATP and increased Pi in animal models and in studies with humans ${ }^{20,21}$.

It is possible that mitochondrial injury represents the underlying basis of the ${ }^{1} \mathrm{H}-\mathrm{MRS}$ and ${ }^{31} \mathrm{P}$-MRS metabolic changes seen in MTS patients considering that NAA is synthesized only in neuronal mitochondria ${ }^{22}$ and it is strongly correlated with oxidative metabolism ${ }^{23}$ and disturbances in energy metabolism were the main finding in previous ${ }^{31} \mathrm{P}-\mathrm{MRS}$ studies.

Mitochondrial oxidative stress and dysfunction appear to represent not only a consequence of seizures but may indeed be related to epileptogenesis ${ }^{24}$. Epilepsy frequently occurs in association with inherited mitochondrial disorders, such as myoclonic epilepsy and mitochondrial encephalomyopathy, lactic acidosis, and stroke-like episodes ${ }^{25}$, which is additional evidence that mitochondrial dysfunction has a role in epilepsy. Furthermore, mice that are partially deficient in a critical mitochondrial antioxidant have a decreased seizure thresh$\mathrm{old}^{26}$. Other evidence for the role of mitochondrial dysfunction in seizure generation in humans is the increased prevalence of epilepsy with aging. Mitochondrial oxidative stress is a well established mechanism of aging and age-related degenerative disease ${ }^{27}$.

Our study is limited by the size of the MRS voxels with contamination from the surrounding structures, especially considering that the number of phase encoding steps was limited by the time of scanning. Only patients with MTS were studied, thus it is unclear if this abnormality is typical of MTS or can happen in other epilepsies. All the patients in our sample were receiving multiple epilepsy drugs and were scheduled for surgery due to refractoriness; therefore no attempt was made to stratify them according to medical therapy. Another limitation is that the absence of seizure was questionnaire based instead of EEG proven in the 48 hours prior to exam. Therefore internal and external validities were limited by the aforementioned shortcomings.

It is currently unknown whether the control of refractory epilepsy with medication or after epilepsy surgery will result in normalization of energy metabolism parameters. It is also unclear whether the correction of metabolic abnormalities may contribute to seizure control and improvement of the cognitive and psychiatric symptoms of refractory epilepsy.

Future studies should investigate the correlation between energetic changes and other factors associated with refractory epilepsy, such as seizure severity, epilepsy features and etiologies, cognitive and psychiatric complications and the postoperative outcome.

A better understanding of the energy dysfunction profile may elucidate the features associated with refractoriness and brain dysfunction associated with chronic epilepsy.

In conclusion, our results indicate extratemporal energetic dysfunction in patients with epilepsy associated with unilateral MTS.

\section{References}

\footnotetext{
1. Falconer M, Serafetinides E, Corsellis J. Etiology and pathogenesis of temporal lobe epilepsy. Arch Neurol. 1964;10(3):233-48. doi:10.1001/archneur.1964.00460150003001

2. Engel J, Brown WJ, Kuhl DE, Phelps ME, Mazziotta JC, Crandall $\mathrm{PH}$. Pathological findings underlying focal temporal lobe hypometabolism in partial epilepsy. Ann Neurol. 1982;12(6):518-28. doi:10.1002/ana.410120604
}

3. Bouilleret V, Semah F, Chassoux F, Mantzaridez M, Biraben A, Trebossen R et al. Basal ganglia involvement in temporal lobe epilepsy: a functional and morphologic study. Neurology. 2008;70(3):177-84. doi:10.1212/01.wnl.0000297514.47695.48

4. Jokeit H, Seitz RJ, Markowitsch HJ, Neumann N, Witte OW, Ebner A. Prefrontal asymmetric interictal glucose hypometabolism and cognitive impairment in patients with temporal lobe epilepsy. Brain. 1997;120(12):2283-94. doi:10.1093/brain/120.12.2283 
5. Pan JW, Williamson A, Cavus I, Hetherington HP, Zaveri H, Petroff OAC et al. Neurometabolism in human epilepsy. Epilepsia. 2008;49(Suppl s3):31-41. doi:10.1111/j.1528-1167.2008.01508.x

6. Pillai JJ, Williams HT, Faro S. Functional imaging in temporal lobe epilepsy. Semin Ultrasound CT MR. 2007;28(6):437-50. doi:10.1053/j.sult.2007.09.006

7. Capizzano AA, Vermathen P, Laxer KD, Matson GB, Maudsley AA, Soher BJ et al. Multisection proton MR spectroscopy for mesial temporal lobe epilepsy. AJNR Am J Neuroradiol. 2002;23(8):1359-68.

8. Cendes F, Caramanos Z, Andermann F, Dubeau F, Arnold DL. Proton magnetic resonance spectroscopic imaging and magnetic resonance imaging volumetry in the lateralization of temporal lobe epilepsy: a series of 100 patients. Ann Neurol. 1997;42(5):737-46. doi:10.1002/ana.410420510

9. Connelly A, Jackson GD, Duncan JS, King MD, Gadian DG. Magnetic resonance spectroscopy in temporal lobe epilepsy. Neurology. 1994;44(8):1411-7. doi:10.1212/WNL.44.8.1411

10. Kuzniecky R, Hugg JW, Hetherington $\mathrm{H}$, Butterworth E, Bilir E, Faught E et al. Relative utility of $1 \mathrm{H}$ spectroscopic imaging and hippocampal volumetry in the lateralization of mesial temporal lobe epilepsy. Neurology. 1998;51(1):66-71. doi:10.1212/WNL.51.1.66

11. Hetherington HP, Kuzniecky RI, Vives K, Devinsky O, Pacia S, Luciano $D$ et al. A subcortical network of dysfunction in TLE measured by magnetic resonance spectroscopy. Neurology. 2007;69(24):2256-65. doi:10.1212/01.wnl.0000286945.21270.6d

12. Kuzniecky R, Hugg J, Hetherington H, Martin R, Faught E, Morawetz $\mathrm{R}$ et al. Predictive value of $1 \mathrm{H}$ MRSI for outcome in temporal lobectomy. Neurology. 1999;53(4):694-8.

13. Menuel C, Guillevin R, Costalat R. Perrin M, Sahli-Amor M, MartinDuverneuil N et al. Phosphorus magnetic resonance spectroscopy: brain pathologies applications. J Neuroradiol. 2010;37(2):73-82. doi:10.1016/j.neurad.2009.07.001

14. Chu WJ, Hetherington HP, Kuzniecky RI, Simor T, Mason GF, Elgavish GA. Lateralization of human temporal lobe epilepsy by 31P NMR spectroscopic imaging at 4.1 T. Neurology. 1998;51(2):472-9. doi:10.1212/WNL.51.2.472

15. Pan JW, Kim JH, Cohen-Gadol A, Pan C, Spencer DD, Hetherington HP. Regional energetic dysfunction in hippocampal epilepsy. Acta Neurol Scand. 2005;111(4):218-24. doi:10.1111/j.1600-0404.2005.00398.x
16. Vanhamme L, Boogaart A, Van Huffel S. Improved method for accurate and efficient quantification of MRS data with use of prior knowledge. J Magn Reson. 1997;129(1):35-43. doi:10.1006/jmre.1997.1244

17. Erecińska M, Silver IA. ATP and brain function.J Cereb Blood Flow Metab. 1989;9(1):2-19. doi:10.1038/jcbfm.1989.2

18. Hugg JW, Laxer KD, Matson GB, Maudsley AA, Husted CA, Weiner MW. Lateralization of human focal epilepsy by 31P magnetic resonance spectroscopic imaging. Neurology. 1992;42(10):2011-8. doi:10.1212/WNL.42.10.2011

19. Grond J, Gerson JR, Laxer KD, Hugg JW, Matson GB, Weiner MW. Regional distribution of interictal 31P metabolic changes in patients with temporal lobe epilepsy. Epilepsia. 1998;39(5):527-36.

20. Petroff OA, Prichard JW, Behar KL, Alger JR, Shulman RG. In vivo phosphorus nuclear magnetic resonance spectroscopy in status epilepticus. Ann Neurol. 1984;16(2):169-77. doi:10.1002/ana.410160203

21. Younkin DP, Delivoria-Papadopoulos M, Maris J, Donlon E, Clancy R, Chance B. Cerebral metabolic effects of neonatal seizures measured with in vivo 31P NMR spectroscopy. Ann Neurol. 1986;20(4):513-9. doi:10.1002/ana.410200412

22. Patel TB, Clark JB. Synthesis of $\mathrm{N}$-acetyl-L-aspartate by rat brain mitochondria and its involvement in mitochondrial/cytosolic carbon transport. Biochem J. 1979;184(3):539-46. doi:10.1042/bj1840539

23. Heales SJ, Davies SE, Bates TE, Clark JB. Depletion of brain glutathione is accompanied by impaired mitochondrial function and decreased $\mathrm{N}$-acetyl aspartate concentration. Neurochem Res. 1995;20(1):31-8. doi:10.1007/BF00995149

24. Waldbaum S, Patel M. Mitochondria, oxidative stress, and temporal lobe epilepsy. Epilepsy Res. 2010;88(1):23-45. doi:10.1016/j.eplepsyres.2009.09.020

25. Shoffner JM, Lott MT, Lezza AM, Seibel P, Ballinger SW, Wallace DC. Myoclonic epilepsy and ragged-red fiber disease (MERRF) is associated with a mitochondrial DNA tRNA(Lys) mutation. Cell. 1990;61(6):931-7. doi:10.1016/0092-8674(90)90059-N

26. Yamamoto $\mathrm{H}$, Tang HW. Preventive effect of melatonin against cyanide-induced seizures and lipid peroxidation in mice. Neurosci Lett. 1996;207(2):89-92. doi:10.1016/0304-3940(96)12493-9

27. Forester B, Berlow Y, Harper D, Jensen JE, Lange N, Froimowitz $\mathrm{MP}$ et al. Age-related changes in brain energetics and phospholipid metabolism. NMR Biomed. 2010;23(3):242-50. doi:10.1002/nbm.1444 